\title{
ANÁLISE MICROSCÓPICA DE OOCISTOS DE Criptosporidium spp. EM CALOPSITAS (Nymphicus hollandicus)
}

\author{
MICROSCOPIC ANALYSIS OF CRYPTOSPORIDIUM spp. OOCYSTS IN \\ COCKATIELS (Nymphicus hollandicus)
}

\author{
M. F.C. PANEGOSSI ${ }^{1}{ }^{*}$, E. D. FERRARI ${ }^{1}$, J. C. PEROSSII ${ }^{1}$, W. B. NAGATA ${ }^{1}$, A. A. NAKAMURA ${ }^{1}$, \\ B. C. M. OLIVEIRA ${ }^{1}$, M. V. MEIRELES ${ }^{1}$, K. D. S. BRESCIANI ${ }^{1}$
}

\section{RESUMO}

Cryptosporidium spp. são coccídios intracelulares obrigatórios que se desenvolvem nas microvilosidades das células do epitélio gastrintestinal de hospedeiros vertebrados causando doença com manifestações clínicas ou de caráter assintomático. Em aves, causa infecções de curso agudo envolvendo os tratos respiratórios e digestivos de várias espécies de Psitaciformes. O objetivo do estudo foi pesquisar oocistos de Cryptosporidium spp. em amostras fecais de calopsitas (Nymphicus hollandicus). Um total de 50 calopsitas domésticas, do Município de Araçatuba, São Paulo, foram examinadas. Destas, 22 fêmeas e 20 machos e oito sem identificação do sexo. Em relação a faixa etária sete eram jovens, 26 adultos, 2 idosos e 15 sem idade identificada. Considerando a procedência dessas aves, 26 eram de criatório, 15 de pet shops e nove de outra origem (doação e encontrada nas ruas). A purificação e concentração dos oocistos foi realizada por meio da Técnica de Centrífugo-Flutuação em solução de Sheather, seguida de análise microscópica por meio da Técnica de coloração negativa com Verde Malaquita. Um questionário foi aplicado aos proprietários abordando principalmente informações sobre o sexo, faixa etária, procedência, episódios de diarreia e vermifugação. A análise dos dados constituiu de estatística descritiva e teste exato de Fisher para verificar associações entre as variáveis. Episódios diarreicos foram relatados em quatro calopsitas. Com a análise microscópica, foram encontradas sete lâminas suspeitas para o parasito e 43 negativas. A ocorrência de Cryptosporidium spp. em fezes de calopsitas foi de 14\% (7/50), por meio da análise microscópica e não houve associação significativa entre as variáveis $(\mathrm{p}<0,05)$. A prevalência amostral encontrada foi alta, sendo detectados oocistos de Cryptosporidium spp. nas fezes desta espécie animal por análise microscópica.

PALAVRA-CHAVES: AVES. VERDE MALAQUITA. PARASITOLOGIA.

ÁREA TEMÁTICA: Doenças Parasitárias 